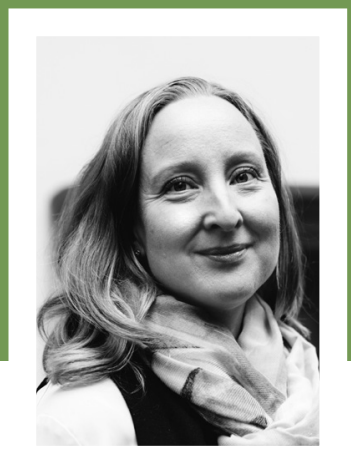

\title{
P̈̈̈̈KIRJOITUS
}

\section{PAINEET KYPSYTTÄVÄT HUIPPUSUORITTAJAN}

$\int \begin{aligned} & \text { ULKISUUDESSA ON VIIME AIKOINA puhuttanut } \\ & \text { erityisesti nuorten lukiolaisten ja yliopisto-opiskeli- }\end{aligned}$ joiden jaksaminen tulevaisuutta koskevien valintojen ja vaatimusten ristipaineissa. Löytyykö oma paikka opintojen jälkeen työelämästä, onko se mieluinen ja mitä se vaatii? Nuoret aikuiset siirtyvät koulutuksesta työelämään vain huomatakseen, että heiltä odotetaan sielläkin yhä uusia näyttöjä ja jatkuvaa uuden opettelua.

Opiskelijoille ja työssäkäyville aikuisille paineita kasaa ajassamme vallitseva uusliberalistinen huippusuorittamisen eetos. Yhteiskunnassamme arvostetaan kilpailua ja menestystä. Sekä työssä että vapaalla ihannoidaan ulkoisista rajoitteista vapaata toimijaa, joka tavoittelee omia unelmiaan ja pyrkii jatkuvasti kehittämään itseään ja parantamaan suoritustaan. Aikuiskoulutus ja työssä oppiminen palvelevat itsensä muokkaamisen hyveitä.

HUIPPUSUORITTAMISEN IDEAALI houkuttelee, tarjoaahan se mahdollisuuksia vaikuttaa omaan tulevaisuuteen ja saavuttaa arvostettuja päämääriä. Se puhuttelee yksilöitä kompetentteina toimijoina, joissa uinuu toteutumatonta lupausta ja potentiaalia. Mitä korkeammalle koulutus- ja urapolulla kiipeää, sitä vahvemmin huippusuorittamisen diskurssi kietoutuu omaan tekemiseen ja toimintaan. Läpäisevänä ohjenuorana on "enemmän, paremmin ja nopeammin".
Samalla kun suorituspaineet kasvavat, myös epävarmuus, levottomuus, stressi ja ahdistuneisuus lisääntyvät. Aiemmat kokemukset koulutus- ja urapolulla ja vertailu muihin samanikäisiin tai samassa uravaiheessa oleviin voivat vahvistaa epäilyjä omasta kyvykkyydestä. Paineita kasvattaa entisestään tietoisuus siitä, että epäonnistumisella ja huippujen ulkopuolelle jäämisellä, voi olla konkreettisia seurauksia elintasoon, elämäntapaan ja elämässä pärjämiseen.

Selitystä ja ratkaisua ahdistaviin tilanteisiin työpaikalla ja uralla haetaan omista toimintatavoista, ominaisuuksista ja mielentilasta; ongelmia ei tunnisteta rakenteista tai sosiaalisista käytännöistä johtuviksi, kuten brittiläinen sosiologian professori ja feministitutkija Rosalind Gill kollegoineen on todennut (esim. Gill \& Orgad 2018). Suorituskeskeisessä kulttuurissa on tärkeintä säilyttää myönteinen asenne ja kääntää ongelmat henkilökohtaisiksi kehittymishaasteiksi.

Olemme yhdessä dosentti Päivi Siivosen ja yliopistonlehtori Maija Korhosen kanssa tarkastelleet kriittisesti työelämässä menestymistä ja uupumista normalisoivia ja haastavia tulkintoja. On ollut kiinnostava havaita, kuinka huippusuorittamisen ideaaliin kuuluu myös huolehtia menestyksekkäästi omasta terveydestä ja hyvinvoinnista. Suoritusta tulee venyttää jaksamisen rajoille asti, mutta samalla ennaltaehkäistä totaalista loppuun palamista. Uudenlaisena "kansalaistaitona" 
peräänkuulutetaan resilienssiä eli peräänantamattomuutta, sitkeyttä ja kykyä toipua vastoinkäymisistä.

HUIPPUSUORITTAMISEN PAINEET ja tasapainottelut ovat tuttuja tutkijallekin: Yliopistomaailmassa joutuu kohtaamaan kilpailua työpaikoista ja rahoituksesta. Itseä vertaillaan toisiin tutkijoihin. Sekä omaa että tutkimusryhmän tuloksellisuutta mitataan toistuvasti muun muassa julkaisujen määrillä ja Jufoluokituksilla. Kovat tavoitteet ja arvioinnin kohteena oleminen ovat omiaan ruokkimaan riittämättömyyttä, mihin puolestaan pyritään vastaamaan entistä paremmilla suorituksilla. Tutkija Mona Mannevuon (2019) sanoin yliopistojen huipukkuutta ihannoivassa työkulttuurissa piilee uupumisriski juuri siksi, että kaikki käyvät ylikierroksilla.

Kaikki eivät kuitenkaan tunnista opiskeluun, työhön ja tutkijuuteen kuuluvia paineita. Jotkut kenties ajattelevat, että ne eivät kosketa heitä. Etäisyyden ottamista suoritusihanteisiin edesauttaa kenties jo saavutettu menestys jollain elämänalueella, turvattu toimeentulo ja sosiaaliset tukiverkot, joihin voi varauksetta luottaa. Monet niistäkin, jotka eivät vallitsevaa huippusuorittamisen ideaalia halua tai pysty täyttämään, haluaisivat kuitenkin tulla osallisiksi siitä hyvästä, jota nyt vain huipulla oleville, menestyjille jaetaan.

Se, miten erilaisista taustoista ja elämäntilanteista tulevat asemoituvat suhteessa kulttuurisiin ja sosiaalisiin normeihin, ei kuitenkaan ole vain itsestä kiinni. On siis turha syyllistää yksilöä paineiden ottamisesta.
Kehotus laskea rimaa ja asettaa itselleen päämääriä vain suhteessa käytettävissä oleviin resursseihin ei sekään kanna kovin pitkälle.

Sen sijaan olisi hyvä kysyä, millaiset rakenteelliset muutokset rakentavat systeemiä, joka ei palkitse liiallisesta suorittamisesta ja itsensä venyttämisestä äärirajoille. Perustavaa muutosta tarvitaan sekä arvostuksissamme että arvioinnin ja palkitsemisen käytännöissä. Uusi ideaali voisi olla yhteiskunta, jossa omaa arvoaan ei tarvitsisi todistella jatkuvalla itsensä ylittämisellä.

\section{Ulpukka Isopahkala-Bouret}

\section{Lisää aiheesta:}

Gill, R. \& Orgad, S.(2018). The Amazing BounceBackable Woman: Resilience and the Psychological Turn in Neoliberalism. Sociological Research Online, 23(2), 477-495.

Korhonen, M., Siivonen, P. \& Isopahkala-Bouret, U. (arvioitavana). Sinnikkään työntekijän ihanne ja haavoittuvuus naisten asiantuntijatyössä. Teoksessa: E. Laakkonen, T. Sotkasiira, M. Heikkilä \& I. Lehto (toim.). Haavoilla. Käsite ja kokemus. Jyväskylän yliopisto: SoPhi.

Mannevuo, M. (2019): Kun työuupumus on normaali olotila - maaninen työkulttuuri kasvattaa tahattomasti työnarkomaaneja. Kolumni 8.4.2019. Yle. https://yle.fi/ uutiset/3-10678362 